$\begin{array}{lllllllllllllllllll}\text { D } & \text { I } & S & P & \text { U } & \text { T } & \text { A } & R & \text { E } & \text { N } & \text { E } & C & \text { E } & \text { S } & \text { S } & \text { E } & \text { E } & S & T\end{array}$

Zeszyty Prawnicze

20.2 / 2020, s. 319-334

DOI 10.21697/zp.2020.20.2.17

PIOTR ZAPADKA

Uniwersytet Kardynała Stefana Wyszyńskiego

\title{
POZYCJA WSPÓŁPRACOWNIKÓW BANKU (DORADCÓW) JAKO POŚREDNIKÓW W OFEROWANIU OBLIGACJI KORPORACYJNYCH NA PRZYKŁADZIE SPRAWY GETBACK
}

\section{WSTĘP}

Przedmiotem niniejszego artykułu jest analiza w zakresie prawnego charakteru czynności wykonywanych przez współpracowników jednego z banków krajowych (dalej: „bank”), tj. osób współpracujących z bankiem (doradców) na podstawie umowy o współpracy, na rzecz klientów tego banku (dalej: „klienci” lub „inwestorzy”) w związku z niepubliczną ofertą nabycia obligacji GetBack S.A. z siedzibą w Warszawie (dalej: „obligacje”). Tematyka ta jest o tyle istotna, że poza znaną medialnie sprawą osób poszkodowanych w wyniku emisji obligacji Get Back S.A., dotyczy ona pozycji prawnej współpracowników banku (doradców) jako uczestniczących w oferowaniu tego rodzaju papierów wartościowych na rzecz swoich klientów - która to pozycja prawna rodzi wiele wątpliwości interpretacyjnych. 


\section{STAN FAKTYCZNY}

Działania podejmowane przez współpracowników banku były związane $\mathrm{z}$ wykonywaniem przez bank, na rzecz jednego $\mathrm{z}$ domów maklerskich (dalej: „oferujący” lub „dom maklerski”), tzw. umów konsorcjum, które przewidywały między innymi zobowiązanie banku do dystrybucji propozycji nabycia obligacji za pośrednictwem narzędzia informatycznego, udostępnianego przez oferującego, w postaci zabezpieczonej ścieżki dostępu do propozycji nabycia obligacji, umieszczonej na stronie internetowej oferującego (link) (dalej: „umowy konsorcjum”)'. Warto przy tym zaznaczyć, że umowy konsorcjum przewidywały, iż oferta niepubliczna/oferta prywatna polegała na skierowaniu do nie więcej niż 149 indywidualnie oznaczonych adresatów propozycji nabycia obligacji, $\mathrm{w}$ postaci nieprzenoszalnego oraz poufnego zaproszenia do złożenia zapisu na obligacje, w treści ustalonej przez Zarząd GetBack S.A. z siedzibą w Warszawie (dalej: „emitent”).

Należy przy tym przyjąć (jako pewne założenia), że usługę świadczoną przez bank na rzecz oferującego można byłoby nazwać usługą w zakresie dystrybucji informacji i propozycji nabycia obligacji, z pewnymi elementami umowy agencyjnej. Co więcej, bezspornie oferującym w rozumieniu art. 69 ust. 2 pkt 6 ustawy o obrocie instrumentami finansowymi ${ }^{2}$, w okresie zawierania umów konsorcjum (tj. w okresie pierwszego kwartału 2018 r.) był przywołany powyżej dom maklerski, posiadający status prawny firmy inwestycyjnej.

Dom maklerski zlecał bankowi czynności pośrednictwa w proponowaniu nabycia obligacji $\mathrm{w}$ ramach oferty niepublicznej obligacji, w szczególności polegających na dystrybucji propozycji nabycia obligacji za pośrednictwem narzędzia informatycznego, udostępnianego przez oferującego - co można potraktować jako informowanie inwestorów o „ofercie produktowej” podmiotu, innego niż bank. Tym samym bank informował swoich klientów, że możliwe jest złożenie zapisów na

1 Decyzja częściowa Prezesa Urzędu Ochrony Konkurencji i Konsumentów z 1 sierpnia 2019 r., Nr RBG 13/2019, znak RBG.610.03.18.AS, s. 12.

2 Ustawa z 29 lipca 2005 r. o obrocie instrumentami finansowymi (tekst jedn. Dz. U. z 2020 r. poz. 89). 
obligacje z wykorzystaniem formularza przyjęcia propozycji nabycia obligacji - który to formularz dostępny był wyłącznie na stronie internetowej oferującego (domu maklerskiego). Bank nie był zatem stroną tych czynności prawnych (w rozumieniu czynności przyjmowania/ odbierania od osób trzecich wiążącego zobowiązania, jakim jest zapis na obligacje) i nie dokonywał również czynności prawnych na rachunek oferującego (nie zawierał umów ani w imieniu emitenta, ani oferującego).

Należy założyć, że przyjęta konstrukcja prawna skutkowała zawiązaniem węzła zobowiązaniowego w ramach subskrypcji obligacji pomiędzy (bezpośrednio) inwestorem i domem maklerskim oraz emitentem. Zauważyć także należy, że na podstawie omawianej propozycji nabycia obligacji inwestor (przyszły obligatariusz) miał podjąć decyzję inwestycyjną i złożyć elektroniczny formularz przyjęcia propozycji nabycia obligacji. W konsekwencji, samo nabycie obligacji następować miało bez udziału banku, poprzez przyjęcie przez inwestorów propozycji nabycia obligacji za pośrednictwem narzędzia informatycznego przygotowanego i administrowanego przez dom maklerski - czyli złożenie zapisu bezpośrednio oferującemu - na formularzu przyjęcia propozycji nabycia obligacji.

Co istotne dla przedstawianej konstrukcji prawnej, formularz przyjęcia propozycji nabycia obligacji (dalej: „formularz”) miał być składany przez osobę, do której skierowano propozycję nabycia obligacji, w którym to formularzu osoba ta przyjmuje propozycję nabycia obligacji oraz określa (w szczególności) liczbę subskrybowanych obligacji.

Powyższe oznacza, że klient/inwestor, chcąc złożyć oświadczenie woli o przyjęciu propozycji nabycia obligacji, winien złożyć formularz (istniejący przede wszystkim w formie elektronicznej), na skutek czynności zalogowania się do ścieżki dostępu umieszczonej na stronie internetowej oferującego (link), następie złożenia wpisu o przyjęciu propozycji nabycia obligacji wraz z określeniem liczby (wolumenu) subskrybowanych obligacji.

Umowa konsorcjum nie przesądza jednak, czy wymienionych wyżej czynności klient/inwestor miałby dokonywać osobiście, czy też przez inną osobą działającą w imieniu i na rzecz klienta inwestora. 
Należy też zauważyć, że współpracownicy banku (dalej „doradcy”) w większości przypadków byli przedsiębiorcami, prowadzącymi indywidualną działalność gospodarczą na zasadach samozatrudnienia, których łączył z bankiem stosunek prawny oparty na konstrukcji umowy agencyjnej, na podstawie którego doradcy zobowiązywali się, za wynagrodzeniem prowizyjnym, do stałego pośrednictwa finansowego w zakresie produktów będących w ofercie banku, tj. produktów własnych banku i produktów podmiotów, z którymi bank zawiera odrębne umowy (partnerów banku), co w analizowanym przypadku miało miejsce, poprzez pośrednictwo finansowe $\mathrm{w}$ związku z obligacjami oferowanymi przez emitenta/ dom maklerski (dalej: „umowa o współpracy”).

Doradcy mieli świadomość, że zasadniczą rolą banku było przekazywanie informacji o możliwości nabycia obligacji i kierowanie zainteresowanych klientów do podmiotów zajmujących się ich dystrybucją (tzw. leadowanie). Z punktu widzenia niniejszych analiz istotnym ustaleniem banku dotyczącym praktyki działań doradców było stwierdzenie, że znaczna część (nawet 80\%) elektronicznych formularzy przyjęcia propozycji nabycia obligacji była wypełniana przez doradców, z tym jednak zastrzeżeniem, iż klienci, do których wysyłane były (drogą e-mailową) wszystkie standardowe informacje o warunkach emisji obligacji/niepublicznej ofercie nabycia obligacji, składali (osobiście) polecenie przelewu środków pieniężnych na pokrycie subskrybowanych obligacji, o czym szerzej niżej.

Powstaje zatem pytanie, jaki charakter prawny miały działania doradców, wypełniających w imieniu klientów banku formularze przyjęcia propozycji nabycia obligacji.

\section{ANALIZA PRZYPADKU}

Należy w tym miejscu zastrzec, że w realiach niniejszej sprawy prawnej ocenie nie będzie podlegać ani zagadnienie zawierania umów poza lokalem lub na odległość przez konsumentów, ani zagadnienie związane $\mathrm{z}$ badaniem/ankietowaniem stanu wiedzy klientów w świetle wymogów 
MIFID $^{3}$, ani też zagadnienie zachowania przez oferującego stosownych form prawnych związanych ze składaniem oświadczeń woli (zapisów) w ramach procesu subskrypcji obligacji, z tej racji, iż ani bank, ani doradcy banku nie byli stroną tego podstawowego stosunku prawnego związanego z emisją obligacji (węzeł obligacyjny emitenta i obligatariusza) i pełna odpowiedzialność prawna w tym zakresie spoczywa bezpośrednio na domu maklerskim lub emitencie.

Powyższe oznacza, że ocenie może podlegać przede wszystkim charakter prawny działań doradców, w ramach (zakresie) zobowiązań banku wynikających z umowy konsorcjum i jednocześnie zobowiązań doradców wynikających z umowy o współpracy, którzy to doradcy $\mathrm{w}$ imieniu i na rzecz klientów banku wypełniali formularz przyjęcia propozycji nabycia obligacji, a który to formularz miał zapewnić złożenie bezpośrednio oferującemu oświadczenia woli inwestorów (zapisy na obligacje), z wykorzystaniem linku do strony internetowej oferującego.

Co istotne, czynność polegająca na wypełnieniu przez doradcę formularza poprzedzona była otrzymaniem przez klienta (drogą e-mailową) podstawowych informacji o warunkach emisji obligacji - zaś po wypełnieniu przez doradcę formularza - klient składał (osobiście) polecenie przelewu środków pieniężnych na pokrycie subskrybowanych obligacji ${ }^{4}$.

Należy zatem przyjąć, dla potrzeb prowadzenia dalszych analiz, że klient jeszcze przed wypełnieniem przez doradcę formularza w imieniu i na rzecz klienta znał podstawowe założenia oferty (warunki emisji obligacji), a zatem wiedział, jakie papiery wartościowe mogą być nabywane,

\footnotetext{
Regulacje określane mianem MIFID tworzą następujące dyrektywy: dyrektywa 2004/39/WE Parlamentu Europejskiego i Rady z 21 kwietnia 2004 r. w sprawie rynków instrumentów finansowych (tzw. MIFID I) oraz dyrektywa 2006/73/WE Komisji z 10 sierpnia 2006 r. wprowadzająca środki wykonawcze do dyrektywy 2004/39/ WE Parlamentu Europejskiego i Rady w odniesieniu do wymogów organizacyjnych i warunków prowadzenia działalności przez przedsiębiorstwa inwestycyjne oraz pojęć zdefiniowanych na potrzeby tejże dyrektywy, oraz dyrektywa 2014/65/UE z 15 maja 2014 r. w sprawie rynków instrumentów finansowych oraz zmieniająca dyrektywę 2002/92/WE i dyrektywę 2011/61/UE (tzw. MIFID II).

4 Decyzja częściowa Prezesa Urzędu Ochrony Konkurencji i Konsumentów z 1 sierpnia 2019 r., Nr RBG 13/2019, znak RBG.610.03.18.AS, s. 12.
} 
kto jest ich emitentem, jaka jest wartość nominalna, jakie są dostępne wolumeny w zakresie oferowanych obligacji, jaka jest ich rentowność, etc.

Co więcej, należy założyć, że podstawowe założenia tej oferty musiały być przedmiotem ustaleń/dyskusji pomiędzy doradcą i klientem czy to w formie rozmowy telefonicznej, czy w formie rozmowy bezpośredniej, ponieważ bez takich wiążących ustaleń, choćby w zakresie wolumenu nabywanych obligacji, doradca nie wiedziałby, jaką liczbę obligacji wpisać w treść formularza.

Skoro, co już zostało powyżej zauważone, umowa konsorcjum nie przesądza, czy czynność polegającą na złożeniu formularza klient miałby dokonywać osobiście, czy też przez inną osobę działającą w imieniu i na rzecz klienta, możliwe jest zastosowanie ogólnych zasad prawa cywilnego w zakresie działania przez przedstawiciela (art. 95 i n. k.c.) ${ }^{5}$.

Dla przypomnienia, wskazać należy, że w świetle przywołanego art. 95 k.c. można dokonać czynności prawnej przez przedstawiciela (z zastrzeżeniem wyjątków przewidzianych w ustawie albo wynikających z właściwości czynności prawnej), zaś czynność prawna dokonana przez przedstawiciela w granicach umocowania pociąga za sobą skutki bezpośrednio dla reprezentowanego. Jest to tzw. zastępstwo bezpośrednie, przez które rozumie się działanie w cudzym imieniu na podstawie odpowiedniego upoważnienia i ze skutkami bezpośrednio dla reprezentowanego - czyli działanie przedstawiciela w imieniu reprezentowanego i na jego rzecz. Jak wskazuje się w literaturze prawniczej, konstrukcja przedstawicielstwa w swojej istocie przypisuje przedstawicielowi możliwość działania w sensie przejawu woli, natomiast podmiotowi sfery praw (reprezentowanemu) - skutek tego działania. W związku $\mathrm{z}$ tym rozwiązaniu legislacyjnemu przyjętemu w art. $95 \$ 2$ k.c. odpowiada ujęcie przedstawicielstwa, zgodnie z którym przejaw woli złożony przez przedstawiciela $\mathrm{w}$ imieniu reprezentowanego powoduje takie konsekwencje, jak gdyby działał sam reprezentowany ${ }^{6}$. W przypadku dokonania czynności przez przedstawiciela następuje swoisty stan zwią-

5 Ustawa z 23 kwietnia 1964 r. - Kodeks cywilny (tekst jedn. Dz. U. z 2019 r. poz. $1145 \mathrm{ze} \mathrm{zm}$.).

6 W. SzydŁo, Przedstawicielstwo ustawowe jako forma reprezentacji, «St. Praw.» 2/2008, s. 90 . 
zania, co oznacza, że reprezentowany nie może zapobiec w swojej sferze prawnej skutków czynności dokonanej przez przedstawiciela, w granicach przysługującej mu kompetencji.

W normatywnym pojęciu przedstawicielstwa nie mieści się bowiem tzw. zastępstwo pośrednie, jak fiducjarne zlecenie czy komis, przy którym zastępca działa na zewnątrz w imieniu własnym i ze skutkami prawnymi bezpośrednio dla siebie. Czynność prawna dokonana przez przedstawiciela i w zakresie jego umocowania powoduje powstanie praw lub obowiązków bezpośrednio po stronie reprezentowanego. Przedstawicielstwo, jak się przyjmuje zarówno w orzecznictwie, jak i w literaturze, jest instytucją pozwalającą przedstawicielowi wywołać skutki bezpośrednio odnoszące się do reprezentowanego, przy czym nie zawsze są to skutki objęte terminem „czynność prawna”, jakkolwiek pełnomocnictwo $z$ definicji zawiera umocowanie do dokonania czynności prawnej. Nie jest czynnością prawną wystąpienie pełnomocnika przed sądem w imieniu mocodawcy, jak też wykonywanie przez niego czynności faktycznej w zakresie pośrednictwa i świadczenia określonych usług.

Alternatywą do koncepcji przedstawicielstwa byłaby koncepcja posłańca w rozumieniu art. 85 k.c. Możliwe jest bowiem przeniesienie oświadczenia woli jednej osoby przez drugą, występującą w roli posłańca. Posłaniec nie składa przy tym własnego oświadczenia woli, co powoduje, że obojętne jest to, czy ma - i w jakim zakresie - zdolność do czynności prawnych. Nie musi także ani znać treści przenoszonego oświadczenia, ani jej rozumieć 7 . W literaturze przedmiotu wskazuje się, że posłaniec to podmiot wybrany przez składającego oświadczenie woli, którego zadaniem jest dostarczenie oświadczenia do adresata. Może być nim zarówno osoba fizyczna, jak i osoba prawna, a także jednostka organizacyjna nieposiadająca osobowości prawnej. Rola posłańca ma charakter techniczny, przy czym nie składa on swego oświadczenia woli, ale jedynie przenosi cudze, którego nie musi ani znać, ani rozumieć. Przykładowo, zgodnie z wyrokiem Sądu Okręgowego w Lublinie

Tak S. RUdnicki, [w:] S. DMOwski, S. RUDNicki, Komentarz do kodeksu cywilnego, ks. 1, Część ogólna, Warszawa 2007, s. 368. 
z 10 lutego 2011 r. $^{8}$ rola posłańca ograniczona jest do tylko jednego zadania: przeniesienia, bez jakichkolwiek zmian, cudzego oświadczenia woli innej, oznaczonej osobie, a więc działanie takiej osoby ma charakter wyłącznie techniczny. W takim sensie posłaniec, w odróżnieniu od przedstawiciela, jest po prostu nośnikiem złożonego przez inną osobę oświadczenia i na tym jego rola się kończy.

W realiach przedmiotowej sprawy najważniejsze jest jednak to, że posłaniec nie składa własnego oświadczenia; jego zadaniem jest tylko przekazanie cudzego gotowego oświadczenia woli, którego treści zresztą nie musi znać i często nie zna. Ponieważ formularz określa (w szczególności) liczbę subskrybowanych obligacji, należy przyjąć, że doradca, wypełniając ten formularz na rzecz klienta, musiał znać choćby tak istotny element oświadczenia woli klienta, jakim jest zamiar co do nabycia określonej liczby (wolumenu) subskrybowanych obligacji.

Bez tej wiedzy doradca nie mógłby skutecznie wypełnić formularza. A zatem należy przyjąć, że doradca, działając w uzgodnieniu z klientem, znał treść oświadczenia woli klienta i złożył to oświadczenie (poprzez wypełnienie formularza), działając jako przedstawiciel - nie zaś jako posłaniec. Jeśli zatem klient, w trakcie rozmowy z doradcą, sformułował do doradcy prośbę o wypełnienie przez doradcę formularza na rachunek klienta, ze wskazaniem określonego wolumenu obligacji, które chciałby nabyć, a w ślad za tym doradca złożył zapis na te obligacje w formularzu, który to zapis jest wiążącym oświadczeniem woli o nabyciu papierów wartościowych, uznać należy, że doradca złożył takie oświadczenie woli na rachunek klienta, przez co nie mógł działać jako posłaniec w prezentowanym powyżej znaczeniu wykonawcy czynności technicznej (nośnika) oświadczenia osoby trzeciej.

Należy przy tej okazji przypomnieć, że w analizowanym przypadku złożenie zapisu jest traktowane jako złożenie oświadczenia o przyjęciu oferty. Innymi słowy, z momentem złożenia i opłacenia zapisu przez inwestora zawierana jest umowa, na podstawie której inwestor obejmuje obligacje i staje się obligatariuszem. A zatem o ile propozycja nabycia obligacji była ofertą zawarcia umowy, w rozumieniu art. 66 k.c., to zapis

8 Wyrok SO w Lublinie z 10 lutego 2011 r. (II Ca 26/11), «Lex» nr 1713600. 
stanowił czynność przyjęcia tej oferty. Przy tej specyfice zapisu należy zaklasyfikować wypełnianie formularza raczej jako składanie oświadczenia woli, co w realiach niniejszej sprawy pozwala uznać „aktywne” działanie doradcy jako działanie przedstawiciela - w przeciwieństwie do „biernego” działania posłańca.

Zgodnie $\mathrm{z}$ art. 96 k.c. umocowanie do działania w cudzym imieniu może opierać się na oświadczeniu reprezentowanego - czyli na pełnomocnictwie. W literaturze przedmiotu wskazuje się, że udzielenie pełnomocnictwa jest jednostronną czynnością prawną mocodawcy.

Jak trafnie zauważył Sąd Najwyższy w wyroku z 29 listopada 2012 r. ${ }^{9}$, konsekwencją umocowania pełnomocnika jest powstanie stosunku pełnomocnictwa, łączącego mocodawcę z pełnomocnikiem, którego istota polega na upoważnieniu pełnomocnika do działania w imieniu i ze skutkami dla mocodawcy. Powstaniu tych skutków mocodawca nie może się przeciwstawić, dopóki trwa stosunek pełnomocnictwa. O pozycji pełnomocnika i skutkach oświadczeń woli składanych przez pełnomocnika w imieniu mocodawcy przesądza również Sąd Najwyższy w wyroku z 31 sierpnia 2017 r. (V CSK 675/16), odnoszącym się do ustalenia rzeczywistej woli stron, gdzie sąd wskazuje, że jeżeli oświadczenie woli prowadzące do zawarcia umowy składa pełnomocnik w imieniu reprezentowanego, ustalenia rzeczywistej woli stron należy dokonywać z punktu widzenia składającego oświadczenie pełnomocnika (art. 95 w zw. z art. 65 k.c.). Udzielenie pełnomocnictwa następuje w drodze jednostronnej czynności prawnej (oświadczenia woli) mocodawcy i nie rodzi po stronie pełnomocnika obowiązku wykonania czynności, do których jest on upoważniony. Obowiązek taki może wynikać z odrębnego stosunku, tzw. podstawowego (wewnętrznego). Jeżeli jednak stosunek taki, określający, jaki użytek pełnomocnik powinien uczynić z udzielonego mu umocowania, nie został przez strony ustanowiony, nie oznacza to, że pełnomocnik pozostaje w pełni swobodny względem mocodawcy w zakresie decyzji co do sposobu wykorzystania przyznanej mu mocy skutecznego zastępowania go w podejmowaniu oznaczonych w pełnomocnictwie czynności.

\footnotetext{
9 Wyrok SN z 29 listopada 2012 r. (V CSK 568/11), «Lex» nr 1289053.
} 
U podstaw stosunku pełnomocnictwa leży zaufanie, wyrażające się w założeniu, że podmiot upoważniony do działania w imieniu i na rzecz innej osoby będzie realizował znaną mu wolę tej osoby, a co najmniej działał w zgodzie z jej interesem.

Przy tej okazji należy dodatkowo podkreślić specyfikę obszaru bankowości, jaką jest bankowość prywatna (private banking), która opiera się na świadczeniu usług na rzecz wyselekcjonowanych klientów banku w oparciu o przywołany powyżej węzeł zaufania. Specyfika usługi typu private banking, która jest dość popularnym we współczesnych gospodarkach wolnorynkowych sposobem obsługi najzamożniejszych klientów przez banki, opiera się na istnieniu szczególnej więzi pomiędzy osobistym doradcą klienta banku (delegowanym przez bank do pełnienia tej funkcji) a klientem banku. Owa szczególna więź jest bowiem oparta na wytworzonym pomiędzy pracownikiem banku a klientem banku węźle zaufania i poufności, a zatem pewnym typie powiernictwa, co powoduje, że osoba wyznaczona przez bank do pełnienia roli osobistego doradcy dla klienta private banking, poza kompetencjami zawodowymi z obszaru finansów, jest traktowana przez klienta jako swoisty powiernik, z którym współpraca opiera się na nieco innych zasadach niż w przypadku „wystandaryzowanych” klientów obszarów bankowości detalicznej lub bankowości korporacyjnej. Według wzorców przyjętych we współczesnych gospodarkach wolnorynkowych, klienta świadczonej przez bank usługi typu private banking, będącej najbardziej wyrafinowaną formułą bezpośredniego kontaktu banku z jego klientem, który powierza bankowi (w pełnym zaufaniu) środki pieniężne lub inne aktywa stanowiące niejednokrotnie dorobek jego całego życia, nie powinno zajmować weryfikowanie zgodności z prawem ofert składanych mu (przy zachowaniu wspomnianej poufności) przez osobistego doradcę - delegowanego do tego zadania przez bank. Dlatego też, w realiach niniejszej sprawy, przedstawiana klientom banku oferta w zakresie subskrypcji obligacji mogła opierać się na nieco innych zasadach niż w przypadku „wystandaryzowanych” klientów bankowości detalicznej lub korporacyjnej - choćby poprzez ustne zlecanie przez klienta określonych czynności, jakie miał na jego rzecz wykonać doradca. 
W tym miejscu warto jest zatem przypomnieć, że składające się na udzielenie pełnomocnictwa oświadczenie woli może zostać złożone $\mathrm{w}$ formie dowolnej. W tym zakresie znajduje zastosowanie art. 60 k.c. (oświadczenie woli), zgodnie z którym - z zastrzeżeniem wyjątków przewidzianych w ustawie - wola osoby dokonującej czynności prawnej może zostać wyrażona przez każde zachowanie się tej osoby, które ujawnia jej wolę w sposób dostateczny, w tym również przez ujawnienie tej woli w postaci elektronicznej. Natomiast art. 99 k.c. przewiduje dwa wyjątki od wskazanej wyżej zasady, gdy udzielenie pełnomocnictwa wymaga zachowania formy szczególnej. Pierwszy z nich dotyczy czynności prawnej, dla której ważności wymagana jest forma szczególna (np. pełnomocnictwo do zawarcia umowy przeniesienia prawa własności nieruchomości wymaga formy aktu notarialnego), natomiast drugi odnosi się do pełnomocnictwa ogólnego (umocowanie do czynności zwykłego zarządu). Dalsze wyjątki mogą wynikać z innych przepisów kodeksu cywilnego oraz z odrębnych ustaw.

Takie wnioskowanie znajduje potwierdzenie także w orzeczeniach sądów. Przykładowo, zgodnie z wyrokiem Sądu Apelacyjnego w Krakowie z 14 czerwca 2016 r. $^{10}$, dotyczącym formy udzielenia pełnomocnictwa, sąd wskazał, że co do zasady forma udzielenia pełnomocnictwa jest dowolna, natomiast wyjątki od tej reguły wskazane są w art. $99 \$ 1$ i 2 k.c.

Jeśli założyć, że w realiach omawianej sprawy doradcy działali jako pełnomocnicy klientów banku, w zakresie czynności polegającej na wypełnieniu formularza, co skutkowało zarówno złożeniem oświadczenia woli nabycia obligacji w imieniu i na rzecz klientów, jak i (technicznym) wypełnieniem formularza, czynność ta ani nie wymagała zachowania formy szczególnej dla pełnomocnictwa, ani też nie była czynnością w ramach zwykłego zarządu - co wymagałoby działania doradcy na podstawie pełnomocnictwa ogólnego.

Wniosek o braku formy szczególnej dla pełnomocnictwa do wypełnienia na rzecz klienta formularza nie wynika $z$ analizy normatywnej zasad przeprowadzania subskrypcji obligacji, gdyż (tak jak to już zostało wskazane wyżej) są to zagadnienia, za jakie odpowiedzialność ponosi

10 Wyrok SA w Krakowie z 14 czerwca 2016 r. (I ACa 298/16), «Lex» nr 2075742. 
oferujący obligacje - nie zaś bank/doradca, którzy jedynie udostępniają klientowi link do strony internetowej oferującego. Jeśli bowiem założyć, że oferujący uznał wypełnienie przez inwestora (przyszłego obligatariusza) formularza jako czynność zgodną z regułami subskrypcji obligacji (zapis na obligacje) - to nic nie stało na przeszkodzie, aby dla zachowania skutków takiej subskrypcji wypełnienia formularza dokonał także pełnomocnik inwestora.

W konsekwencji uprawniony jest wniosek, że pełnomocnictwo do wypełnienia formularza przez doradcę mogło zostać przez klienta złożone w dowolnej formie - w tym także formie ustnej.

Należy zwrócić uwagę również na art. $103 \$ 1$ k.c., zgodnie z którym jeżeli zawierający umowę jako pełnomocnik nie ma umocowania do albo przekroczy jego zakres, ważność umowy zależy od jej potwierdzenia przez osobę, w imieniu której umowa została zawarta. Przy czym potwierdzenie to nie wymaga formy szczególnej; możliwe jest także dokonanie potwierdzenia w sposób dorozumiany (czynności konkludentne), choćby poprzez przystąpienie do wykonania umowy. Dorozumiane potwierdzenie może się wyrażać w przystąpieniu przez rzekomego mocodawcę do wykonania umowy, o ile ten wiedział o jej zawarciu w jego imieniu przez rzekomego pełnomocnika (tak np. wyrok Sądu Apelacyjnego w Łodzi z 4 września 2013 r. ${ }^{11}$ dotyczący formy dorozumianego potwierdzenia umowy zawartej przez pełnomocnika bez umocowania). Podobne tezy zawiera postanowienie Sądu Apelacyjnego w Warszawie z 17 października 2000 r. $^{12}$, gdzie sąd wskazał, że w wypadku, gdy pełnomocnik nie ma upoważnienia do dokonania danej czynności prawnej lub działa z przekroczeniem udzielonego mu pełnomocnictwa, to potwierdzenie tej czynności przez osobę, w której imieniu działał, czyni ją skuteczną. Analogicznie rzecz się ma w przypadku praw procesowych, czego przykładem jest wyrok Wojewódzkiego Sądu Administracyjnego w Szczecinie z 4 czerwca 2009 r. ${ }^{13}$, w którym sąd wskazał, że jeżeli pełnomocnik nie ma umocowania albo przekro-

11 Wyrok SA w Łodzi z 4 września 2013 r. (III AUa 1759/12), «Lex» nr 1409147.

12 Postanowienie SA w Warszawie z 17 października 2000 r. (I ACa 119/00), «Lex» nr 48367.

13 Wyrok WSA w Szczecinie z 4 czerwca 2009 r. (I SA/Sz 209/09), «Lex» nr 511570. 
czy jego zakres, ważność dokonanych na rzecz strony czynności prawnych w postępowaniu przed organem nie może być potwierdzona przez stronę, na rzecz której działał. Warto przy tym zauważyć, że zgodnie z wyrokiem Sądu Apelacyjnego w Łodzi z 14 lutego 2013 r. ${ }^{14}$ dotyczącym warunków potwierdzenia czynności dokonanej przez fałszywego pełnomocnika, aby można mówić o potwierdzeniu czynności dokonanej przez fałszywego pełnomocnika, trzeba, po pierwsze, wiedzieć, że mamy do czynienia z taką właśnie czynnością, a po drugie, znać wszystkie istotne elementy tej czynności.

W realiach analizowanej sprawy takim potwierdzeniem dla działań doradcy (występującego w charakterze pełnomocnika klienta) byłoby przystąpienie przez klienta do wykonania umowy, co miało miejsce w wyniku składania przez klientów poleceń przelewów bankowych na poczet pokrycia subskrybowanych obligacji.

Należy uznać, że (kierując się przywołanym wyrokiem Sądu Apelacyjnego w Łodzi z 14 lutego 2013 r.) klienci musieli znać „istotne elementy czynności” dokonanej w ich imieniu przez pełnomocnika (doradcę), skoro dokonali przelewu bankowego o określonej wartości nominalnej - umożliwiając w ten sposób nabycie konkretnej liczby (wolumenu) obligacji.

Ponieważ, tak jak to już zostało wskazane, bank nie był upoważniony do przyjmowania formularzy przyjęcia propozycji nabycia obligacji, $\mathrm{w}$ omawianym zakresie wypełniania formularzy, doradcy w ramach dokonywanych czynności nie działali jako pełnomocnicy banku.

Relacja pomiędzy doradcami i bankiem jest ściśle określona i wynika z treści zawartej przez te strony umowy o współpracę.

Innym zagadnieniem jest brak starannego działania po stronie klienta, który upoważnił doradcę do działania w jego imieniu, bez szczegółowego zapoznania się z treścią formularza. Przykładowo, zgodnie z wyrokiem Sądu Apelacyjnego w Warszawie z 12 lipca 2017 r. ${ }^{15}$ dotyczącego udzielenia pełnomocnictwa do głosowania nad konkretną uchwałą wspólnoty mieszkaniowej bez zapoznania się z treścią tej uchwały, sąd wskazał, że

14 Wyrok SA w Łodzi z 14 lutego 2013 r. (I ACa 1117/12), «Lex» nr 1289495.

15 Wyrok SA w Warszawie z 12 lipca 2017 r. (I ACa 650/16), «Lex» nr 2402423. 
jeżeli mocodawca przez własne zaniedbanie udzielił pełnomocnictwa do głosowania nad konkretną uchwałą bez zapoznania się z treścią tej uchwały (projektu), to takie własne niedbalstwo nie upoważnia go do powoływania się wobec wspólnoty na błąd. Z drugiej strony, okolicznością, która może nieco mitygować brak ewentualnego starannego działania po stronie klienta, jest przywołana powyżej specyficzna relacja pomiędzy klientem i doradcą, wynikająca ze swoistego węzła zaufania, jaki tworzony jest w obszarze bankowości prywatnej (private banking), a który daje klientowi podstawy do zaufania w czynności podejmowane/ oferowane przez doradcę.

Na zakończenie warto też zauważyć, że doradcy wielokrotnie wskazywali na fakt, iż byli proszeni przez klientów o pomoc w wypełnieniu formularzy, co dodatkowo potwierdza tezę o udzielonych przez klientów pełnomocnictwach do tego rodzaju czynności.

\section{Podsumowanie}

Konkludując badane zagadnienie, stwierdzić należy, że:

a. doradcy działali na zasadach przedstawicielstwa, dokonując czynności prawnych i faktycznych na rzecz klientów banku;

b. klienci banku, po uzyskaniu kluczowych informacji na temat warunków emisji obligacji, udzielili doradcom pełnomocnictwa w formie dorozumianej (ustnej), na podstawie którego doradcy, znając podstawowe warunki przyjęcia oferty nabycia obligacji przez klientów, wypełnili w imieniu i na rzecz klientów formularz administrowany przez oferującego, składając w ten sposób skuteczne prawnie oświadczenie woli nabycia określonej liczby (wolumenu) obligacji;

c. klienci banku, w sposób konkludentny, potwierdzili czynności dokonane w ich imieniu przez doradców, składając bankowe polecenia przelewu środków pieniężnych na pokrycie subskrybowanych obligacji, w kwocie nominalnej odpowiadającej wolumenowi i wartości obligacji, jakie wpisane zostały przez doradców w formularzu. 
POZYCJA WSPÓ£PRACOWNIKÓW BANKU (DORADCÓW) JAKO POŚREDNIKÓW W OFEROWANIU OBLIGACJI KORPORACYJNYCH NAPRZYKŁADZIE SPRAWY GETBACK

\section{Streszczenie}

Przedmiotem niniejszego artykułu jest analiza w zakresie prawnego charakteru czynności wykonywanych przez współpracowników jednego z banków krajowych, tj. osób współpracujących z bankiem (doradców) na podstawie umowy o współpracy, na rzecz klientów tego banku w związku z niepubliczną ofertą nabycia obligacji GetBack S.A. $\mathrm{z}$ siedzibą w Warszawie.

Metodologia badania - przyjętą metodologią jest metodologia normatywno-dogmatyczna.

Wynik - wynikiem badań jest wykonanie wykładni prawnej w zakresie badanego zagadnienia.

Oryginalność/Wartość - tematyka ta jest o tyle istotna, gdyż poza znaną medialnie sprawą osób poszkodowanych w wyniku emisji obligacji GetBack S.A., dotyczy ona pozycji prawnej współpracowników banku (doradców) - jako uczestniczących w oferowaniu tego rodzaju papierów wartościowych na rzecz swoich klientów - która to pozycja prawna rodzi wiele wątpliwości interpretacyjnych.

Legal Status of Bank Advisors Acting as Agents Selling Corporate Bonds: A Case Study of the GetBack Affair

\section{Summary}

The aim of this article is to examine the legal status of bank employees (advisors) acting as agents selling its corporate bonds, on the basis of a case study of the GetBack affair. The research methodology is based on the analysis of legal texts and interpretations. The result obtained in this study is a legal interpretation of the case. The article presents an original approach to understanding the legal framework of business conducted by Polish financial institutions. Apart from the situation of 
the victims of the GetBack bank affair, which was widely reported in the media, another aspect which came to light as a result of the scandal and requires scrutiny is the dubious legal status of the agents selling the bank's corporate bonds to its customers.

Słowa kluczowe: GetBack S.A.; bank; obligacje; klienci.

Keywords: GetBack S.A.; bank; corporate bonds; bank customers.

\section{Literatura:}

SzydŁo W., Przedstawicielstwo ustawowe jako forma reprezentacji, «Studia Prawnicze» 2/2008, s. 87-129.

Rudnicki S., [w:] S. Dmowski, S. Rudnicki, Komentarz do kodeksu cywilnego, ks. 1, Część ogólna, Warszawa 2007. 